\title{
DIDELĖS RIZIKOS SKYRIŲ SLAUGOS PERSONALO ŽINIŲ APIE HOSPITALINES INFEKCIJAS İVERTINIMAS
}

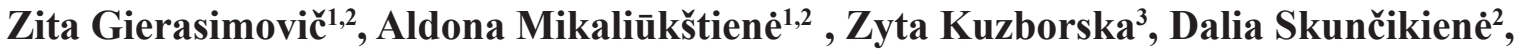 \\ Jelena Kutkauskiené ${ }^{4}$ \\ ${ }^{1}$ Vilniaus universiteto Medicinos fakulteto Sveikatos moksly institutas, \\ ${ }^{2}$ Vilniaus universiteto ligoninès Santaros klinikos, \\ ${ }^{3}$ Vilniaus Gedimino technikos universitetas, \\ ${ }^{4}$ Mykolo Romerio universiteto Teisès mokyklos Viešosios teisès institutas
}

Raktažodžiai: hospitalinè infekcija, žinios, rizikos veiksniai, prevencijos priemonès.

\begin{abstract}
Santrauka
Darbo tikslas. İvertinti didelès rizikos skyrių slaugos personalo žinias apie hospitalines infekcijas.

Tyrimo medžiaga ir metodai. Tyrimas atliktas vienoje Vilniaus miesto universiteto ligonineje. Dalyvavo 110 slaugytojų, dirbančių ligoninès didelès rizikos skyriuose. Tiriamieji apklausti naudojantis autorių sudarytu klausimynu. Statistinè duomenų analizè atlikta naudojant IBM SPSS Statistics 19,0 ir Microsoft Office Excel 2016 programas. Taikyti aprašomosios statistikos metodai. Statistinio patikimumo rodiklis vertintas, kai p reikšmė ne didesnè kaip 0,05 $(\mathrm{p} \leq 0,05)$ ir daroma išvada, kad skirtumai yra statistiškai reikšmingi.

Darbo rezultatai ir išvados. Daugiau nei puse tiriamujju (59,1 proc.), dažniau aukštesnio išsilavinimo (67,5 ir 72,2 proc.) bei turintys didesnę darbo patirtį, teisingai apibūdino hospitalinę infekciją. Hospitalinès infekcijos rizikos veiksnius žinojo daugiau nei pusè (58,2 proc.) tiriamujų, dažniau dirbantys iki 10 metų. Kaip labai didelę ir didelę hospitalinès infekcijos riziką dauguma apklaustujų nurodè šlapimo takų kateterio (70 proc.), centrinès venos katerio (52,7 proc.), rečiau - intubacinio vamzdelio (29,1 proc.), nazogastrinio zondo ( 24,5 proc.) buvimą bei intubacinio vamzdelio ištraukimą ( 16,4 proc.). Turintys aukštaji neuniversitetinį išsilavinimą dažniau prie didelès rizikos veiksnių priskyrè centrinès venos ( 77,8 proc.), šlapimo takų (53,7 proc.) kateteriu buvimą. Didžioji dauguma tiriamujų teikè prioritetą
\end{abstract}

prevencinių priemonių (pirštinių keitimas, rankų higiena) taikymui atliekant invazines procedūras, tačiau pirštinių keitimą tarp dviejų skirtingų procedūrų kai kurie tyrimo dalyviai (19,1 proc.) priskyre vidutiniškai svarbiam veiksniui. Mažesnè tiriamųjų dalis $(9,1$ proc.) neteike prioriteto pirštinių keitimo procedūrai po kontakto su aplinkos paviršiumi. Visi tiriamieji po kontakto su biologine tarša pirštinių keitimą nurodė kaip svarbų veiksnị.

\section{Ivadas}

Slaugos personalo veikla turi didelę reikšmę hospitalinių infekcijų (toliau - HI) prevencijai. Personalo žinios apie HI, jų atsiradimo riziką, prevencijos planavimą ir turimų žinių taikymas praktikoje išsaugo paciento gyvybę. Tai ypač aktualu didelès rizikos skyrių pacientams, turintiems didesnę tikimybę igyti HI [1]. Mikroorganizmų kolonizavimas ir infekcijos atsiradimas priklauso nuo paciento būklès, imuniteto, gretutinių susirgimų, amžiaus, ilgalaikio antibiotikų vartojimo, invazinių procedūrų ir kita [2]. Išoriniai rizikos veiksniai - kraujagyslinių, šlapimo takų kateterių, dirbtinès plaučių ventiliacijos naudojimas 5-10 kartų didina riziką susirgti HI [3, 4]. Didžiausias HI paplitimas registruojamas (2014) didelès rizikos skyriuose [5]. HI paplitimas šiuose skyriuose siekia 18 proc., o bendras sergamumas HI juose siekia nuo 12,8 iki 38 procentų [6]. Kas dešimtam didelès rizikos skyriaus pacientui nustatoma $\mathrm{HI}$, tuo tarpu bendras $\mathrm{HI}$ paplitimas Lietuvoje panašus, kaip ir daugelyje Europos šalių [7]. PSO duomenimis (2011), HI ES šalyse siekia 17 atvejų 1000 gydymosi dienų, apie 30 proc. didelès rizikos skyriuose besigydančiu pacientų igyja $\mathrm{HI}$ [8]. Lietuvoje bendras sergamumas HI šiuose skyriuose $2016 \mathrm{~m}$. buvo 17,9 proc., o $2017 \mathrm{~m}$. - 16,1 procento [7-8]. Prioritetinè HI prevencijos 
planavimo kryptis yra slaugos personalo žinios ir jų praktinis taikymas slaugos procese. Žinių apie HI stoka ir klaidingi prioritetai atliekant invazines procedūras, dažnai paliekami slaugytojų savikontrolei [9].

Tyrimo tikslas - įvertinti didelès rizikos skyrių slaugos personalo žinias apie HI.

\section{Medžiaga ir metodai}

Trijų mėnesių tyrime dalyvavo vienos Vilniaus miesto universiteto ligoninès didelès rizikos skyrių slaugos personalas. Anketavimo būdu vertintos 110 slaugos personalo žinios apie HI. Anketa sudaryta iš dviejų dalių: bendrosios dalies (profesinè darbo patirtis, išsilavinimas), specialiosios dalies, kurioje nagrinėjami pagrindiniai klausimai apie HI, jų priežastis, rizikos veiksnius, HI prevenciją. Atsakymai ị klausimus vertinti pagal teisingo atsakymo pasirinkimą. Vertinant profesinę darbo patirtį, tiriamieji suskirstyti ị penkias grupes pagal darbinès patirties trukmę: nuo mažiau nei vienerių iki 20 metų ir daugiau. HI apibūdinimas vertintas atsakymu ,teisingai“, „iš dalies teisingai“. HI rizikos veiksnių vertinimas: „labai maža ir maža rizika“, „,vidutinè rizika“, „labai didelè ir didelè rizika“. HI rizikos veiksnių paplitimas vertintas balais nuo 1 „mažiausiai paplitusi“ iki 5 „labiausiai paplitusi“. HI prevencinių priemonių naudojimo svarba vertinta balais nuo 1 „mažiausiai svarbu iki 3 „labai svarbu“. Statistinè duomenu analizè atlikta naudojant IBM SPSS Statistics 19,0 ir Microsoft Office Excel 2016programas. Taikyti aprašomosios statistikos metodai. Apskaičiuotos imčių charakteristikos: absoliutus skaičius (n), procentas (proc.). Skirtumai tarp rizikos veiksnių buvo vertinami naudojant Pearson chi kvadrato kriterijų $\left(\chi^{2}\right)$. Statistinio patikimumo rodiklis vertintas, kai $\mathrm{p}$ reikšmé ne didesnè kaip $0,05(\mathrm{p} \leq 0,05)$ ir daroma išvada, kad skirtumai yra statistiškai reikšmingi.

1 lentelè. Tiriamųjų išsilavinimas ir darbo trukmė

\begin{tabular}{|l|c|c|c|c|}
\hline \multirow{2}{*}{$\begin{array}{l}\text { Darbo trukmė } \\
n=110\end{array}$} & \multicolumn{3}{|c|}{ Išsilavinimas } \\
\cline { 3 - 5 } \multicolumn{2}{|l|}{} & aukštesnysis & $\begin{array}{c}\text { aukštasis } \\
\text { neuniversite- } \\
\text { tinis } \\
40(36,4)\end{array}$ & $\begin{array}{c}\text { aukštasis } \\
\text { universitetinis } \\
54(49,1)\end{array}$ \\
\hline Metai & n (proc.) & n (proc.) & n (proc.) & $n$ (proc.) \\
\hline$<1$ & $5(4,5)$ & $1(6,3)$ & $3(7,5)$ & $1(1,9)$ \\
\hline $1-5$ & $19(17,3)$ & $2(12,4)$ & $3(7,5)$ & $14(25,9)$ \\
\hline $6-10$ & $18(16,4)$ & $1(6,3)$ & $6(15,0)$ & $11(20,4)$ \\
\hline $11-20$ & $33(30,0)$ & $6(37,5)$ & $9(22,5)$ & $18(33,3)$ \\
\hline$>20$ & $35(31,8)$ & $6(37,5)$ & $19(47,5)$ & $10(18,5)$ \\
\hline
\end{tabular}

\section{Tiriamieji}

Iš visų $(\mathrm{n}=110)$ dalyvavusių tyrime, kone pusè $(49,1$ proc.) buvo igiję aukštaji universitetinį išsilavinimą, trečdalis (36,4 proc.) - aukštajị neuniversitetini, likusioji dalis - aukštesniji (14,5 proc.). Dauguma tyrimo dalyvių dirbo 11 ir daugiau metų: trečdalis tiriamujjų turejjo daugiau nei 20 metų $(31,8$ proc.) ir $11-20$ metų $(30,0$ proc.) profesinę darbo patirti, mažiausia dalis (4,5 proc.) - iki vienerių metų (1 lentelè).

\section{Rezultatai}

Vertintos tiriamujų žinios apie HI prevencines priemones, HI paplitimo, rizikos veiksnius.

Apklausos dalyviai turejo apibūdinti HI. Teisingai HI apibūdino daugiau nei pusè (59,1 proc.), likusieji -tik iš dalies (40,9 proc.) (1 pav.).

Vertinome tiriamujų žinias apie HI, atsižvelgiant i darbinę patirtị ir išsilavinimą. Rezultatai parodè, kad tiriamieji, turintys 6-10 ir 11-20 metų darbo patirti, geriau žinojo ir teisingai apibūdino HI (77,8 proc. ir 72,7 proc., $p=0,023)$, palyginti su turinčiais trumpesnę, ar ilgesnę nei 20 metų, darbo patirti (2 lentelè). Teisingų HI apibūdinimų skaičius, didejjant išsilavinimui, daugejo, tačiau statistikai reikšmingas skirtumas nenustatytas $(\mathrm{p}=0,481)$ ( 3 lentelè).

HI rizikos veiksnių vertinimas. Daugiau nei pusè tiriamuju ( 58,2 proc.) ir dažniau mažesnę darbinę patirtị (iki $10 \mathrm{~m}$.) turintys teisingai įvardino HI rizikos veiksnius $(\mathrm{p}=0,0001)$ (4 lentelè).

Dauguma tiriamuju pažymèjo po kelis HI plitimo rizikos veiksnius. Kaip labai didelę ir didelę HI riziką daugelis apklaustujų nurodè su medicinos priemonių (prietaisų) naudojimu susijusius rizikos veiksnius: šlapimo takų kateterio (70 proc.) , centrinès venos katerio (52,7 proc.), rečiau - intubacinio vamzdelio (29,1 proc.), nazogastrinio zondo buvimą ( 24,5 proc.) ir intubacinio vamzdelio išèmimą ( 16,4 proc.).

Labai didelès ir didelès HI rizikos veiksnių atpažini-

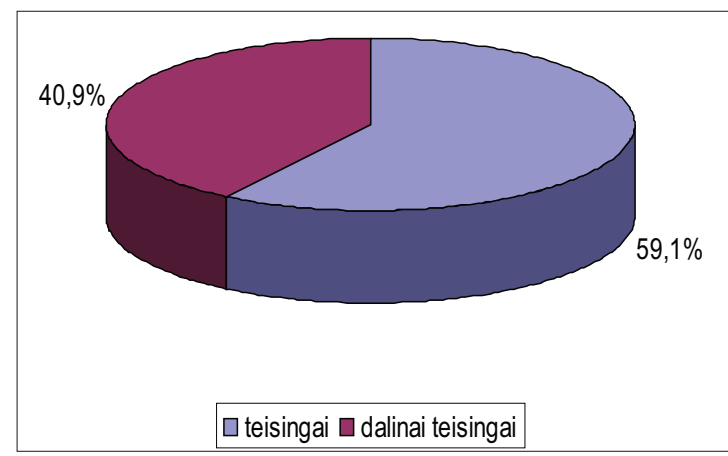

1 pav. HI apibūdinimas 
mas priklausė nuo tiriamujų darbinès patirties: centrinès venos kateterio naudojimo riziką dažniau rinkosi 1-5 metus dirbantys; šlapimo taku kateterio ir intubacinio vamzdelio naudojimą - dirbantys 6-10 ir 11-20 metų. Intubacinio vamzdelio išèmimą ( 48,6 proc.), nazogastrinio zondo buvimą ( 65,7 roc.) daugiau nei 20 metų dirbantys žymèjo kaip labai mažą ir mažą HI rizikos veiksnị (5 lentelè).

Dauguma tiriamujų, nepriklausomai nuo išsilavinimo, centrinès venos ir šlapimo taku kateterių buvimą priskiria prie labai didelių HI rizikos veiksnių; aukštajị neuniversitetinị išsilavinimą turintys tiriamieji prioritetiniu rizikos veiksniu žymejjo centrinès venos ( 77,8 proc.), šlapimo takų $(53,7$ proc.) kateterių buvimą. 34,6 proc. intubacini vamzdeli priskiria prie labai didelio HI sukeliančio rizikos veiksnio; 30,9 proc. tiriamųų intubacinio vamzdelio išèmimo procesą priskiria labai didelei ir didelei HI rizikai. Dažniau šį atsakymą rinkosi turintys aukštaji universitetini išsilavinimą. Nazogastrinio zondo buvimą, kaip labai mažos rizikos veiksnį, dažniau pažymèjo turintieji aukštesnijji (61,1 proc.) ar aukštaji universitetinị (70,0 proc.) išsilavinimą (6 lentelè).

HI struktūroje dauguma tiriamųų pneumoniją (76,4 proc.) ir sepsị (58,2 proc.) pažymėjo kaip labai paplitusị veiksnį, turintị įtakos HI atsiradimui. Apatinių kvėpavimo takų infekcijas 40,9 proc. tiriamujų pažymèjo, kaip vidutiniškai paplitusias; 26,4 proc. tiriamujų operacinių žaizdų infekcijas priskyre prie mažai paplitusių HI infekcijų; 28,1 proc. tiriamųjų šlapimo takų infekcijas pažymėjo kaip mažai paplitusias (2 pav.).

Dauguma tiriamujų pažymėjo didelę rankų higienos svarbą: prieš kontaktą su imliais pacientais (97,3 proc.), po kontakto su biologiniais skysčiais (100 proc.), dalijant maistą (84,5 proc.). Kas šeštas (15,5 proc.) apklausos dalyvis teigè, kad rankų higiena prieš dalijant maistą yra „mažiausiai svarbu“; kas penktas (19,1 proc.) - kad rankų higiena tarp procedūrų yra ,vidutiniškai svarbu“" (7 lentelè).

Medicininių pirštinių mūvèjimo svarbą prieš invazines procedūras ir prieš kontaktą su biologiniais skysčiais pažymėjo visi (100 proc.) tiriamieji. Didžioji dauguma žymèjo, kad ,labai svarbu" mūvèti pirštines po kontakto su aplin- kos paviršiais (86,4 proc.), kai nėra galimybès nusiplauti rankų $(88,2$ proc.). Daugiau nei pusė $(59,1$ proc.) pažymèjo, kad mūvèti pirštines prieš dalijant maistą yra „mažiausiai svarbu“ (7 lentelè).

\section{Aptarimas}

Tyrimu siekta ịvertinti didelès rizikos skyrių slaugos personalo žinias apie HI. Gautų atsakymų analizè atskleidè, kad daugiau nei pusè tiriamụjų žinojo teisingą HI apibūdinimą. Dažniau teisingus atsakymus pažymėjo turintys aukštajị universitetinį išsilavinimą ir 6-20 metų darbinę patirtị. Daugiau nei puse tiriamujų teisingai ịvertino HI rizikos veiksnius, o iš dalies teisingus atsakymus pateikè daugiau nei pusè tiriamujų, turinčių 11-20 ir per 20 metų darbo patirti. Tai patvirtina ir kitų HI paplitimo rizikos veiksnius vertinančių tyrimų duomenys [10-12].

Daugelis autorių nurodo, kad HI paplitimas didelès rizikos skyriuose yra didesnis, nei kituose skyriuose $[4,7,13]$. HI rizikos veiksnių buvimas ar neteisingas jų vertinimas gali lemti infekcijos išplitimą [5,14-15]. Didžioji tiriamųų, turinčių aukštaji neuniversitetinị išsilavinimą, dalis, nurodè vieną pagrindinę labai didelès HI rizikos priežastị - centrinès venos kateterio buvimą. Tiriamieji, turintys aukštajị universitetinị išsilavinimą, dažniau žymėjo šlapimo takų kateterio buvimą kaip labai didelès HI rizikos veiksnị. Vertinant atsakymus pagal profesinę darbo patirtį, ši rizikos veiksnị dažniau nurodè visų profesinès darbo patirties grupių tiriamieji. Kas šeštas tiriamasis ignoravo centrinès venos ir šlapimo takų kateterių buvimo riziką. Daugelis autorių nustatè, kad atliekant invazines procedūras ir ilgesniam laikui paliekant ịvestus kraujagyslinius, šlapimo

2 lentelè. HI apibūdinimo vertinimai, atsižvelgiant ị profesinę darbo patirtị

\begin{tabular}{|c|c|c|c|c|c|c|}
\hline \multirow{2}{*}{$\begin{array}{l}\text { HI } \\
\text { apibūdinimas } \\
(\mathbf{n}=110)\end{array}$} & \multicolumn{5}{|c|}{ Darbo patirtis, metais } & $\mathrm{P}\left(\chi^{2}\right)$ \\
\hline & $\begin{array}{c}<1 \\
(\mathrm{n}=5)\end{array}$ & $\begin{array}{c}1-5 \\
(\mathrm{n}=19)\end{array}$ & $\begin{array}{c}6-10 \\
(\mathrm{n}=18)\end{array}$ & $\begin{array}{c}11-20 \\
(\mathrm{n}=33)\end{array}$ & $\begin{array}{c}<20 \\
(\mathrm{n}=35)\end{array}$ & \multirow{3}{*}{$\begin{array}{c}p \\
=0,023 \\
(11,333)\end{array}$} \\
\hline Teisingai & $2(40,0)$ & $\begin{array}{c}10 \\
(52,6)\end{array}$ & $\begin{array}{c}14 \\
(77,8)\end{array}$ & $\begin{array}{c}25 \\
(72,7)\end{array}$ & $15(42,9)$ & \\
\hline Iš dalies teisingai & $3(60,0)$ & $9(47,4)$ & $4(22,2)$ & $8(24,2)$ & $20(57,1)$ & \\
\hline
\end{tabular}

3 lentelè. HI apibūdinimo vertinimai, atsižvelgiant ị išsilavinimą

\begin{tabular}{|l|c|c|c|c|}
\hline \multirow{2}{*}{$\begin{array}{l}\text { HI apibūdinimas } \\
(\mathbf{n}=110)\end{array}$} & \multicolumn{4}{|c|}{ Išsilavinimas } \\
\cline { 2 - 4 } & $\begin{array}{c}\text { aukštesnysis } \\
(\mathrm{n}=16)\end{array}$ & $\begin{array}{c}\text { aukštasis ne- } \\
\text { universitetinis } \\
(\mathrm{n}=40)\end{array}$ & $\begin{array}{c}\text { aukštasis uni- } \\
\text { versitetinis } \\
(\mathrm{n}=54)\end{array}$ & $\mathrm{P}\left(\chi^{2}\right)$ \\
\hline Teisingai & $9(56,3)$ & $27(67,5)$ & $39(72,2)$ & $\begin{array}{r}\mathrm{p}=0,481 \\
(1,465)\end{array}$ \\
\hline Iš dalies teisingai & $7(43,7)$ & $13(32,5)$ & $15(27,8)$ & \\
\hline
\end{tabular}

4 lentelè. HI rizikos veiksnių vertinimas, atsižvelgiant ị profesinę darbo patirtị

\begin{tabular}{|c|c|c|c|c|c|c|}
\hline \multirow{2}{*}{$\begin{array}{l}\text { Rizikos } \\
\text { veiksniai } \quad(n=110)\end{array}$} & \multicolumn{5}{|c|}{ Darbo patirtis, metais } & $\mathrm{P}\left(\chi^{2}\right)$ \\
\hline & $\begin{array}{l}<1 \\
(\mathrm{n}=5)\end{array}$ & $\begin{array}{ll}1 & -5 \\
(\mathrm{n}=19)\end{array}$ & 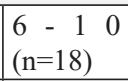 & $\begin{array}{l}1 \begin{array}{l}1 \\
(\mathrm{n}=33)\end{array} \\
\end{array}$ & $\begin{array}{lll}> & 2 & 0 \\
(n=35)\end{array}$ & \multirow{3}{*}{$\begin{array}{l}p=0,0001 \\
(22,795)\end{array}$} \\
\hline $\begin{array}{l}\text { Teisingai } \\
64 \text { (58,2 proc.) }\end{array}$ & $\begin{array}{l}3 \\
(60,0)\end{array}$ & $\begin{array}{l}1 r^{7} \\
(89,5)\end{array}$ & $16(88,9)$ & $13(39,4)$ & $15(42,9)$ & \\
\hline $\begin{array}{l}\text { Iš dalies teisingai } \\
46 \text { ( } 41,8 \text { proc.) }\end{array}$ & $\begin{array}{l}2 \\
(40,0) \\
\end{array}$ & $\begin{array}{l}2 \\
(10,5) \\
\end{array}$ & $2(11,1)$ & $20(60,6)$ & $20(57,1)$ & \\
\hline
\end{tabular}


takų kateterius yra didžiausia HI ịgijimo rizika [6, 16,17]. Panašūs ir kitų tyrejų atliktų tyrimų rezultatai, susijęsu HI paplitimo rizika ir kraujagysliniais, šlapimo takų kateteriais bei dirbtine plaučių ventiliacija $[18,19]$. Kiti autoriai nurodo, kad 83 proc. HI paplitimo atvejų yra susiję su dirbtine plaučių ventiliacija ir šlapimo takų infekcija $[1,20]$, o pacientų imlumas infekcijai labai skiriasi, ypač dèl invazinių procedūrų poreikio $[1,18]$. Nepavyko aptikti kitų autorių tyrimų, kai tiriamieji, turintys ilgesnę profesinę darbinę patirti, vertina HI veiksnius pagal jų rizikos svarbą. Šlapimo takų ir operacinių žaizdų infekcijų buvimas predisponuoja HI atsiradimą. Šị veiksnị pažymėjo didžioji 11-20 ir per 20 metų darbinę patirtị turinčių tiriamujų dalis. Penktadalis tiriamujų pažymėjo pneumoniją, kaip labiausiai paplitusią infekciją HI struktūroje. Europos ligų prevencijos ir kontrolès centro (angl. European centre for disease prevention and control, toliau-ECDC) duomenimis, pneumonijos ir kitos apatinių kvèpavimo takų infekcijos dažniausiai aptinkamos HI struktūroje, po jų nurodomos operacinių žaizdų, šlapimo takų ir kraujo infekcijos [5, 21,22]. Mūsų gautų rezultatų analizè atskleidè, kad trečdalis tiriamųjų nepakankamai ìvertina apatinių kvẻpavimo takų infekcijos, sepsio riziką, šias infekcijas priskiria prie

5 lentelè. HI rizikos veiksnių vertinimas, atsižvelgiant ị darbo patirtị

\begin{tabular}{|c|c|c|c|c|c|c|}
\hline \multirow{2}{*}{$\begin{array}{l}\text { HI rizikos veiksnių } \\
\text { vertinimas }(n=110)\end{array}$} & \multicolumn{6}{|c|}{ Darbo patirtis, metais } \\
\hline & $<1(\mathrm{n}=5)$ & $\begin{array}{c}1-5 \\
(\mathrm{n}=19)\end{array}$ & $\begin{array}{c}6-10 \\
(n=18)\end{array}$ & $\begin{array}{c}11-20 \\
(\mathrm{n}=33) \\
\end{array}$ & $\begin{array}{c}>20 \\
(\mathrm{n}=35)\end{array}$ & $\mathrm{P}\left(\chi^{2}\right)$ \\
\hline \multicolumn{7}{|l|}{ Centrinès venos kateteris } \\
\hline $\begin{array}{l}\text { Labai maža ir maža rizika, } \\
\mathrm{n}=18(16,4 \text { proc.) }\end{array}$ & $3(60,0)$ & - & $3(16,7)$ & $6(18,2)$ & $6(17,1)$ & \multirow{3}{*}{$\begin{array}{l}\mathrm{p}=0,002 \\
(23,988)\end{array}$} \\
\hline $\begin{array}{l}\text { Vidutinė rizika, } \\
\mathrm{n}=34(30,9 \text { proc.) }\end{array}$ & $2(40,0)$ & $1(5,3)$ & $6(33,3)$ & $11(33,3)$ & $14(40,0)$ & \\
\hline $\begin{array}{l}\text { Labai didelè ir didelè rizika, } \\
\mathrm{n}=58(52,7 \text { proc. })\end{array}$ & - & $18(94,7)$ & $9(50,0)$ & $16(48,5)$ & $15(42,9)$ & \\
\hline \multicolumn{7}{|l|}{ Šlapimo takų kateteris } \\
\hline $\begin{array}{l}\text { Labai maža ir maža rizika, } \\
\mathrm{n}=14(12,7 \text { proc.) }\end{array}$ & - & $1(5,3)$ & $1(5,6)$ & - & $12(34,3)$ & \multirow{3}{*}{$\begin{array}{l}\mathrm{p}=0,0001 \\
(47,020)\end{array}$} \\
\hline $\begin{array}{l}\text { Vidutinè rizika, } \mathrm{n}=19(17,3 \\
\text { proc.) }\end{array}$ & $5(100,0)$ & $4(21,0)$ & $2(11,1)$ & $5(15,2)$ & $3(8,6)$ & \\
\hline $\begin{array}{l}\text { Labai didelè ir didelè rizika, } \\
\mathrm{n}=77 \text { ( } 70,0 \text { proc. })\end{array}$ & - & $14(73,7)$ & $15(83,3)$ & $28(84,8)$ & $20(57,1)$ & \\
\hline \multicolumn{7}{|l|}{ Intubacinis vamzdelis } \\
\hline $\begin{array}{l}\text { Labai maža ir maža rizika, } \\
\mathrm{n}=44(40,0 \text { proc.) }\end{array}$ & $4(80,0)$ & $9(47,4)$ & $9(50,0)$ & $13(39,4)$ & $9(25,7)$ & \multirow{3}{*}{$\begin{array}{l}\mathrm{p}=0,281 \\
(9,771)\end{array}$} \\
\hline $\begin{array}{l}\text { Vidutinè rizika, } \\
\mathrm{n}=34(30,9 \text { proc. })\end{array}$ & $1(20,0)$ & $7(36,8)$ & $5(27,8)$ & $9(27,3)$ & $12(34,3)$ & \\
\hline $\begin{array}{l}\text { Labai didelè ir didelè rizika, } \\
\mathrm{n}=32 \text { ( } 29,1 \text { proc.) }\end{array}$ & - & $3(15,8)$ & $4(22,2)$ & $11(33,3)$ & $14(40)$ & \\
\hline \multicolumn{7}{|c|}{ Intubacinio vamzdelio išèmimas } \\
\hline $\begin{array}{l}\text { Labai maža ir maža rizika, } \\
\mathrm{n}=64(58,2 \text { proc.) }\end{array}$ & $5(100)$ & $18(94,7)$ & $3(16,6)$ & $21(63,6)$ & $17(48,6)$ & \multirow[t]{3}{*}{$\begin{array}{r}\mathrm{p}=0,0001 \\
(44,958)\end{array}$} \\
\hline $\begin{array}{l}\text { Vidutinė rizika, } \\
\mathrm{n}=28(25,5 \text { proc. })\end{array}$ & - & - & $14(77,8)$ & $6(18,2)$ & $8(22,8)$ & \\
\hline $\begin{array}{l}\text { Labai didelè ir didelè rizika, } \\
\mathrm{n}=18(16,4 \text { proc. })\end{array}$ & - & $1(5,3)$ & $1(5,6)$ & $6(18,2)$ & $10(28,6)$ & \\
\hline \multicolumn{7}{|l|}{ Nazogastrinis zondas } \\
\hline $\begin{array}{l}\text { Labai maža ir maža rizika, } \\
\mathrm{n}=74(67,3 \text { proc. })\end{array}$ & $3(60,0)$ & $6(31,5)$ & $14(77,8)$ & $28(84,8)$ & $23(65,7)$ & \multirow{3}{*}{$\begin{array}{l}\mathrm{p}=0,002 \\
(23,821)\end{array}$} \\
\hline Vidutinè rizika, $n=9(8,2$ proc. $)$ & - & $1(5,3)$ & $1(5,6)$ & $3(9,1)$ & $4(11,4)$ & \\
\hline $\begin{array}{l}\text { Labai didelè ir didelè rizika, } \\
\mathrm{n}=27(24,5 \text { proc. })\end{array}$ & $2(40,0)$ & $12(63,2)$ & $3(16,6)$ & $2(6,1)$ & $8(22,9)$ & \\
\hline
\end{tabular}

mažiausiai paplitusių. Iš dalies teisingi atsakymo pasirinkimo variantai rodo, kad reikia gerinti slaugos personalo žinias apie dažniausiai pasireiškiančias HI. Kiti autoriai teigia, kad teisingas rizikos veiksnių ivertinimas leidžia tiksliai taikyti prevencines priemones ir saugiai atlikti invazines procedūras $[15,22]$. Mažesnè dalis tiriamujų nepakankamą dèmesị skyrè kryžminei infekcijai ir pirštinių keitimui, kai nèra galimybès nusiplauti rankų prieš procedūrą. Apie trečdalis tiriamujų rankų higieną laikè vidutiniškai svarbiu veiksniu. Kiti tyrejjai atskleide, kad personalo rankos dažnai užterštos HI sukėlèjais [18], o dèl personalo kontakto su aplinka, per rankas, pirštines, aprangą didejja kryžminès infekcijos perdavimo rizika $[19,20]$. Šiu prevencinių priemonių svarbą patvirtina ir kiti tyrèjai $[1,21]$. Mūsų tyrime, mažesnè tiriamųų, iš dalies teisingai pažymèjusių atsakymus apie HI rizikos veiksnius, dalis, pripažista spragas ir norètų žinias apie HI gilinti. Kiti autoriai nurodo, kad sumažinti 20-30 proc. hospitalinių infekcijų paplitimą didelès rizikos skyriuose galima taikant higienos kontrolès programas $[3,5]$. Kiti šaltiniai nurodo, kad priklausomai nuo HI struktūros, infekcijų paplitimą galima sumažinti nuo 70 proc. iki 55 procentų $[3,7]$. Hospitalinių infekcijų prevencijoje slaugos personalas yra pagrindiné saugaus invazinių procedūrų atlikimo grandis, o dažnai teorinių žinių lygis yra geresnis, nei tai rodo praktika $[12,21]$. Mūsų tyrimas rodo, kad ver- 
tinant HI, tiriamujų profesinè darbo patirtis bei išsilavinimas yra iš dalies reikšmingi. Panašūs duomenys gauti ir kitų tyrejjų, kurie taip pat padare išvadą, kad reikalingi periodiniai, teminiai mokymai apie HI [12]. Kaip parodè mūsų tyrimo rezultatai, net ir tais atvejais, kai tiriamuju profesinè darbo patirtis yra per 21 metus, neretai, dažniau klaidingai, HI sukeliantys rizikos veiksniai priskiriami labai mažai ir mažai rizikos grupei. Manoma, kad netinkamas HI rekomendacijų interpretavimas, žinių stoka apie HI formuoja neteisingą požiūrị i $\mathrm{HI}$ ir invazinių procedūru svarbą [11, 23].

\section{Išvados}

1. Daugiau nei pusè tiriamujų, dažniau aukštesnio išsilavinimo ir turintys didesnę darbo patirtị, teisingai apibūdino HI.

2. HI rizikos veiksnius žinojo daugiau nei pusė tiriamųų, dažniau - dirbantys iki 10 metų. Kaip labai didelę ir didelę HI riziką dauguma apklaustujų nurodè šlapimo takų kateterio, centrinès venos kateterio, rečiau - intubacinio vamzdelio, nazogastrinio zondo buvimą bei intubacinio vamzdelio išèmimą. Turintys aukštaji neuniversitetinị išsilavinimą dažniau prie didelès rizikos veiksnių priskyrè centrinès venos ir šlapimo takų kateterių buvimą.

3. Dauguma tiriamujų teikè prioritetą prevencinių priemonių (pirštinių keitimas, rankų higiena) svarbai atliekant invazines procedūras, tačiau penktadalis pirštinių keitimą tarp dviejų skirtingų procedūrų laikè vidutinès svarbos veiksniu. Mažesnè tiriamujų dalis neteikè prioriteto pirštinių keitimo procedūrai po
6 lentelè. HI rizikos veiksnių vertinimas, atsižvelgiant ị išsilavinimą

\begin{tabular}{|c|c|c|c|c|}
\hline \multicolumn{5}{|c|}{ Išsilavinimas } \\
\hline $\begin{array}{l}\text { HI sukeliančių rizikos veiksnių } \\
\text { vertinimas }(n=110)\end{array}$ & $\begin{array}{l}\text { Aukštesnysis } \\
16(\mathrm{n}=14,5)\end{array}$ & $\begin{array}{l}\text { Aukštasis neuni- } \\
\text { versitetinis } \\
54(n=49,1)\end{array}$ & $\begin{array}{l}\text { Aukštasis uni- } \\
\text { versitetinis } \\
40(n=36,4)\end{array}$ & $\mathrm{P}\left(\chi^{2}\right)$ \\
\hline \multicolumn{5}{|c|}{ Centrinès venos kateteris } \\
\hline $\begin{array}{l}\text { Labai maža ir maža rizika, } \\
\mathrm{n}=19(17,3 \text { proc.) }\end{array}$ & $2(12,5)$ & $8(14,8)$ & $9(22,5)$ & \multirow{3}{*}{$\begin{array}{l}p=0,009 \\
(13,606)\end{array}$} \\
\hline Vidutinè rizika, $\mathrm{n}=22$ ( 20,0 proc.) & $6(37,5)$ & $4(7,4)$ & $12(30,0)$ & \\
\hline $\begin{array}{l}\text { Labai didelè ir didelè rizika, } \\
\mathrm{n}=69(62,7 \text { proc. })\end{array}$ & $8(50,0)$ & $42(77,8)$ & $19(47,5)$ & \\
\hline \multicolumn{5}{|c|}{ Šlapimo takų kateteris } \\
\hline $\begin{array}{l}\text { Labai maža ir maža rizika, } \mathrm{n}=36(32,7 \\
\text { proc.) }\end{array}$ & $6(37,5)$ & $19(35,2)$ & $11(27,5)$ & \multirow{3}{*}{$\begin{array}{l}\mathrm{p}=0,284 \\
(5,037)\end{array}$} \\
\hline Vidutinè rizika, $\mathrm{n}=19$ (17,3 proc.) & $5(31,3)$ & $6(11,1)$ & $8(20,0)$ & \\
\hline $\begin{array}{l}\text { Labai didelè ir didelè rizika, } n=55 \\
(50,0 \text { proc.) }\end{array}$ & $5(31,3)$ & $29(53,7)$ & $21(52,5)$ & \\
\hline \multicolumn{5}{|c|}{ Intubacinis vamzdelis } \\
\hline $\begin{array}{l}\text { Labai maža ir maža rizika, } n=26(23,6 \\
\text { proc.) }\end{array}$ & $3(18,7)$ & $13(24,1)$ & $10(25,0)$ & \multirow{3}{*}{$\begin{array}{l}p=0,988 \\
(0,326)\end{array}$} \\
\hline Vidutinè rizika, $\mathrm{n}=46$ ( 41,8 proc.) & $7(43,8)$ & $22(40,7)$ & $17(42,5)$ & \\
\hline $\begin{array}{l}\text { Labai didelè ir didelè rizika, } n=38 \\
(34,6 \text { proc.) }\end{array}$ & $6(37,5)$ & $19(35,2)$ & $13(32,5)$ & \\
\hline \multicolumn{5}{|c|}{ Intubacinio vamzdelio išèmimas } \\
\hline $\begin{array}{l}\text { Labai maža ir maža rizika, } n=48(43,6 \\
\text { proc.) }\end{array}$ & $4(25,0)$ & $29(53,7)$ & $15(37,5)$ & \multirow{3}{*}{$\begin{array}{l}\mathrm{p}=0,002 \\
(16,991)\end{array}$} \\
\hline Vidutinè rizika, $\mathrm{n}=28$ (25,5 proc.) & $8(50,0)$ & $15(27,8)$ & $5(12,5)$ & \\
\hline $\begin{array}{l}\text { Labai didelè ir didelè rizika, } n=34 \\
(30,9 \text { proc.) }\end{array}$ & $4(25,0)$ & $10(18,5)$ & $20(50,0)$ & \\
\hline \multicolumn{5}{|l|}{ Nazogastrinis zondas } \\
\hline $\begin{array}{l}\text { Labai maža ir maža rizika, } \mathrm{n}=74(67,3 \\
\text { proc.) }\end{array}$ & $13(81,3)$ & $33(61,1)$ & $28(70,0)$ & \multirow{3}{*}{$\begin{array}{l}p=0,337 \\
(4,549)\end{array}$} \\
\hline Vidutinè rizika, $\mathrm{n}=9$ ( 8,2 proc. $)$ & $2(12,4)$ & $4(7,4)$ & $3(7,5)$ & \\
\hline $\begin{array}{l}\text { Labai didelè ir didelé } \\
\text { rizika, } n=27 \text { ( } 24,5 \text { proc.) }\end{array}$ & $1(6,3)$ & $17(31,5)$ & $9(22,5)$ & \\
\hline
\end{tabular}

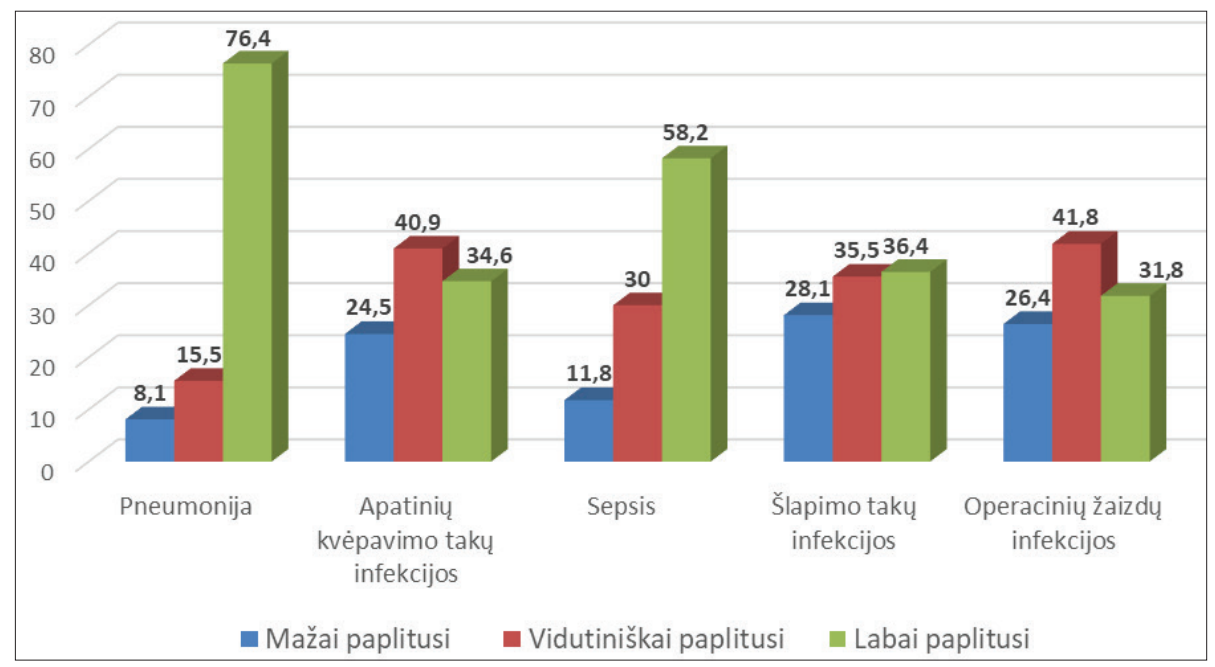

2 pav. HI struktūros vertinimas $\left(\mathrm{p}_{=}=0,0001\right)$ 
7 lentelè. HI prevencinių priemonių naudojimo svarba

\begin{tabular}{|c|c|c|c|c|}
\hline \multirow{3}{*}{ Priemonès } & \multicolumn{4}{|c|}{ Svarbu (balais) } \\
\hline & $\begin{array}{c}1 \\
\text { (mažiausiai } \\
\text { svarbu) }\end{array}$ & $\begin{array}{c}\mathbf{2} \\
\text { (vidutiniškai } \\
\text { svarbu) }\end{array}$ & $\begin{array}{c}\mathbf{3} \\
\text { (labai } \\
\text { svarbu) }\end{array}$ & $\mathrm{p}\left(\chi^{2}\right)$ \\
\hline & $\mathrm{n}$ (proc.) & $\mathrm{n}$ (proc.) & \multicolumn{2}{|c|}{$\mathrm{n}$ (proc.) } \\
\hline \multicolumn{5}{|l|}{ Rankų higiena } \\
\hline $\begin{array}{l}\text { Prieš kontaktą su imliais pa- } \\
\text { cientais }\end{array}$ & - & $3(2,7)$ & $107(97,3)$ & \multirow{4}{*}{$\begin{array}{l}\mathrm{p}=0,0001 \\
(105,195)\end{array}$} \\
\hline $\begin{array}{l}\text { Po kontakto su biologiniais } \\
\text { skysčiais }\end{array}$ & - & - & $110(100,0)$ & \\
\hline Dalijant maistą & $17(15,5)$ & - & $93(84,5)$ & \\
\hline Tarp 2 skirtingų procedūrų & - & $21(19,1)$ & $89(80,9)$ & \\
\hline \multicolumn{5}{|l|}{ Pirštinès } \\
\hline Prieš invazines procedūras & - & - & $110(100,0)$ & \multirow{5}{*}{$\begin{array}{l}p=0,0001 \\
(269,914)\end{array}$} \\
\hline $\begin{array}{l}\text { Prieš kontaktą su biologiniais } \\
\text { skysčiais }\end{array}$ & - & - & $110(100,0)$ & \\
\hline $\begin{array}{l}\text { Po kontakto su aplinkos pa- } \\
\text { viršiais }\end{array}$ & $5(4,5)$ & $10(9,1)$ & $95(86,4)$ & \\
\hline $\begin{array}{l}\text { Kai nèra galimybės tarp proce- } \\
\text { dūrų nusiplauti rankas }\end{array}$ & $13(11,8)$ & - & $97(88,2)$ & \\
\hline Prieš dalijant maistą & $65(59,1)$ & $14(12,7)$ & $31(28,2)$ & \\
\hline
\end{tabular}

kontakto su aplinkos paviršiumi. Visi tiriamieji po kontakto su biologine tarša pirštinių keitimą nurode kaip svarbų veiksnį.

\section{Literatūra}

1. Brusaferro S, Arnoldo L, Cattani G, Fabbro E, Cookson B, Gallagher R, Hartemann P, Holt $\mathrm{J}$, et al. Harmonizing and supporting infection control training in Europe. The Journal of Hospital Infection 2015;89:351-6. https://doi.org/10.1016/j.jhin.2014.12.005

2. Tarybos rekomendacijos dèl pacientų saugos ir su sveikatos priežiūra susijusių infekcijų prevencijos ir kontrolès (2009/C 151/01) iggyvendinimo antroji Komisijos ataskaita Tarybai. Europos Komisija, 2014.

3. Hospitalinių infekcijų epidemiologinè priežiūra reanimacijos-intensyvios terapijos skyriuose. Higienos institutas, 2015.

4. Allegranzi B, Bagheri Nejad S, Combescure C, Graafmans W, Attar H, Donaldson L, Pittet D. Burden of endemic health-care-associated infection in developing countries: systematic review and meta-analysis. Lancet 2011;377:228-41. https://doi.org/10.1016/S0140-6736(10)61458-4

5. European centre for disease prevention and control. Point prevalence survey of healthcare associated infections and antimicrobial use in European acute care hospitals - protocol version 5.3. Stockholm, ECDC 2016.

6. Zingg W, Huttner BD, Sax H, Pittet D. Assessing the burden of healthcare-associated infections through prevalence studies: what is the best method? Infection Control and Hospital Epidemiology 2014;35:674-84.

https://doi.org/10.1086/676424

7. Ašembergienè J., Gurskis V., Kondratas T. Hospitalinès infekcijos Lietuvos reanimacijos ir intensyviosios terapijos skyriuose: nacionalinès hospitalinių infekciju epidemiologinès priežiūros 2009-2011 m. rezultatai. Visuomenès sveikata, 2013;1(60):58-66.

8. Report on the burden of endemic health care-associated infection worldwide. World Health Organization 2011.

9. Carrico RM, Garrett H, Balcom D, Glowicz JB. Infection prevention and control core practices: a roadmap for nursing practice. Nursing 2018;48:2829.

https://doi.org/10.1097/01.NURSE.0000541385.06363.73

10. Magill SS, Edwards JR, Bamberg W, Beldavs ZG, Dumyati G, Kainer MA. Multistate point-prevalence survey of health care-associated infections. The New England Journal of Medicine 2014;370:1198-208.

https://doi.org/10.1056/NEJMoa1306801

11. Reichardt C, Koniger D, Bunte-Schonberger K, van der Linden $\mathrm{P}$, Monch N, Schwab F, Behnke M, Gastmeier P. Three years of national hand hygiene campaign in Germany: what are the key conclusions for clinical practice? The Journal of Hospital Infection 2013;83 (Suppl 1):S11-6.

https://doi.org/10.1016/S01956701(13)60004-3

12. Yates A. Urinary catheter fixation devices: an essential part of catheter management in the community. British Journal of Community Nursing 2014;19:434-5. https://doi.org/10.12968/bjen.2014. 19.9.434

13. Surveillance of surgical site infections in NHS hospitals in England 2013/14. London: Public Health England 2014.

14. El Sakka N, Gould IM. Role of old antimicrobial agents in the management of urinary tract infection. Expert Review of Clinical Pharmacology 2016;9:1047-56. https://doi.org/10.1080/17512433.201 6.1189325

15. Obiero CW, Seale AC, Berkley JA. Empiric treatment of neonatal sepsis in developing countries. The Pediatric Infectious Disease Journal 2015;34:659-61. https://doi org/10.1097/INF.00000000 00000692

16. Tang HJ, Lin HL, Lin YH, Leung PO, 
Chuang YC, Lai CC. The impact of central line insertion bundle on central lineassociated bloodstream infection. BMC Infectious Diseases 2014;14:356.

https://doi.org/10.1186/1471-2334-14-356

17. Folgori L, Bielicki J, Sharland M. A systematic review of strategies for reporting of neonatal hospital acquired bloodstream infections. Archives of Disease in Childhood Fetal and Neonatal Edition 2013;98:F518-23.

https://doi.org/10.1136/archdischild-2012-303149

18. WHO patient safety curriculum guide: multiprofessional edition. Geneva, World Health Organization 2011.

19. Hospitalinių infekcijų epidemiologinè priežiūra reanimacijosintensyvios terapijos skyriuose. Higienos institutas, 2018.

20. Alemagno SA, Guten SM, Warthman S, Young E, Mackay DS. Online learning to improve hand hygiene knowledge and compliance among health care workers. Journal of Continuing Education in Nursing 2010;41:463-71.

https://doi.org/10.3928/00220124-20100610-06

21. Mitchell R, Taylor G, Rudnick W, Alexandre S, Bush K, Forrester L, Frenette C, Granfield B, Gravel-Tropper D, Happe $\mathrm{J}$, et al. Trends in health care-associated infections in acute care hospitals in Canada: an analysis of repeated point prevalence surveys. Canadian Medical Association Journal 2019;191:E981-E988.

https://doi.org/10.1503/cmaj.190361

22. World Health Organization. Report on the burden of endemic health care associated infection worldwide. 2011.

23. Ghorbani A, Sadeghi L, Shahrokhi A, Mohammadpour A, Addo M, Khodadadi E. Hand hygiene compliance before and after wearing gloves among intensive care unit nurses in Iran. Am J Infect Control 2016;44(11):e279-81.

https://doi.org/10.1016/j.ajic.2016.05.004

\section{ON ASSESSING NURSING STAFF EXPOSURE TO HIGH RISK INFECTIONS \\ Z. Gierasimovič, A. Mikaliūkštienè, Z. Kuzborska, D. Skunčikienė, J. Kutkauskienė}

Keywords: hospital infection, knowledge, risk factors, preventive measures.
Summary

Work objective. To assess the knowledge of hospital infections of nursing staff in high-risk units.

Research material and methods. The study took place at one Vilnius University Hospital. 110 nursing staff at high-risk units participated. The subjects were interviewed using the author's questionnaire. Statistical data analysis was performed using IBM SPSS Statistics 19.0 and Microsoft Office Excel 2016. Methods of descriptive statistics were applied. The statistical reliability score was evaluated at a $\mathrm{p}$ value not greater than $0.05(\mathrm{p} \leq 0.05)$ and it is concluded that the differences are statistically significant.

Results and conclusions. More than half of the subjects (59.1\%) and more often those with higher education (67.5\% and $72.2 \%)$ and those with more work experience correctly described HI. More than half $(58.2 \%)$ of the subjects were aware of the risk factors for HI and were more likely to work for up to 10 years. The majority of the respondents identified the urinary catheter $(70 \%)$, central venous catheter $(52.7 \%)$, less frequently the intubation tube $(29.1 \%)$, nasogastric probe (24.5\%) as very high and high risk of HI. ) and reintubation (16.4\%). Those with higher non-university education more often attribute the presence of central veins $(77.8 \%)$ and urinary tract $(53.7 \%)$ as high risk factors. The vast majority of investigative preventive measures (glove replacement, hand hygiene) attribute the importance of priority action to invasive procedures, but $19.1 \%$ of glove replacement between two different procedures. attributes a moderately important factor to the study participants. A smaller proportion $(9.1 \%)$ do not prioritize the glove replacement procedure after contact with the surrounding surface. All subjects report the change of gloves after contact with biological contamination as an important factor.

Correspondence to: zita.gierasimovič@santa.lt

Gauta 2020-01-23 